\title{
Do Social Networks have Effects on the Risk Attitude of Commercial Poultry Farmers? Evidence from Southwest Nigeria
}

\author{
*Oluwakemi Adeola Obayelu, Olukemi Olumuyiwa Olowe, Temitope Grace Faleye \\ University of Ibadan, Ibadan, Nigeria
}

\begin{abstract}
Poultry production decision setting is full of risk and imperfect information. Attitude towards risk is a measure of farmers' willingness to take risks which is an important determinant in their production decisions. Strong social capital emanating from social networks can lead to efficient risk management strategies, thereby minimizing risks faced by the farmers. Therefore, the effects of social capital on the risk attitude of small-scale commercial poultry farmers in Oyo state were assessed. Data were collected from two hundred small-scale farmers and analysed using descriptive and inferential statistics, factorial analysis, multinomial logit and a two-stage least square. Results showed that $52.5 \%, 37.5 \%$ and $10 \%$ of the poultry farmers were risk averse, risk neutral and risk preferring, respectively. About $31.4 \%$ and $68.6 \%$ of the female and male farmers respectively were risk averse. Close to a fifth, a quarter and two-thirds of the risk averse, risk neutral and risk takers respectively contributed $21-30 \%$ of the decisions in the associations. Fourteen percent of the farmers belonged to homogeneous groups. The choice of being risk averse was affected by marital status, educational level, family size, percentage spent on poultry income and aggregate social capital. There was no reverse causality between risk attitude and social capital.
\end{abstract}

Keywords: social capital, risk behaviour, multi-item scale, reverse causality, poultry farmers.

\section{Introduction}

The Nigerian poultry industry was estimated at NGN 80 billion naira (USD 600 million) and made up of about 165 million birds, which produced 650,000 MT of eggs and 290,000 MT of poultry meat in 2013 (Sahel, 2015). This has made the nation the second highest egg producer in Africa after South Africa's 200 million birds. Although the industry is the most commercialized and fastest growing sub-sector of the animal husbandry sector in Nigeria (Heise, Crisanb \& Theuvsenc, 2015), it is encumbered with problems of feed-food competition, reliance on the import of improved breeds, low investment base, lack of equity capital, inefficient production systems, increasing costs of feeds, poor quality chicks, and low level of technological adoption (Alabi \& Isah, 2002; AboulNaga \& Elbeltagy, 2007). The poultry production decision environment is therefore made up of risk and assymetric information. Poultry production faces a myriad of risks including price fluctuation, changes in government policies and production risks, all of which cause profit volatility and affect farmers' behavior with respect to input choice decisions (Picazo-Tadeo \& Wall, 2011). Production risk exists in poultry farming which is caused by the unpredictable weather, disease outbreak and hence uncertainty of poultry outputs (Boehlje, 2002).

The Nigerian poultry sector is highly splintered with most of the chicken raised on small-scale commercial farms with less than 1,000 birds (Sahel, 2015). This unfortunate state of Nigerian poultry production is influenced by attitudes of farmers towards risks of adoption of innovations, which are linked to risks in the production and socioeconomic environments. Risk emanate from direct impact of uncertainties on the decision making process owing to farmers' attitude towards risk. Commercial poultry farming systems in Nigeria is affected by farmers' behavior to production risks. Their attitudes to risks are foremost factors influencing the rate of dissemination of new technologies among the farmers and of the product of rural development interventions

\footnotetext{
* Corresponding Author's email: jkemmyade@yahoo.co.uk
} 
(Yu, Hailu, \& Cao, 2014). Ellis (2000) used income variance approach to classify farmers' production decision behaviour as risk-preferring (willing to take the risk of doing better than expected with a known probability of not doing well as expected); riskneutral (indifferent between certain and uncertain outcomes with the same probable value of income); and risk-averse (prefers certainty of a given income yielding the same projected value for income but which involves uncertainty). Attitude towards risk is a measure of farmers' willingness to take risks which is an important determinant in their production decisions (Jussaume \& Glenna, 2009).

In response to the throng of risk factors associated with farming, farmers have adapted ex-ante and ex-post forms risk management skills (Fafchamps, 1992). Ex-ante methods either reduce the probability of occurrence or reduce the potential impact of a shock while ex-post measures are coping strategies to relieve the impact of a shock after its occurrence. Strong social capital from social networks can contribute to making ex-ante as well as ex-post risk management more efficient, thereby reducing the risk faced by the farmers. This is because social networks encourage dissemination of agricultural innovation.

Social capital refers to social capital related to the formal and informal links, shared values and understandings in society that enable individuals and groups to trust each other and so work together to harness economic opportunities. It is made up of trust, norms, sanctions and flow of information through the social structure (Coleman, 1998; Putnam, 2000). Existing literature on social capital and welfare is vast (Grootaert et al., 2004; Narayan \& Pritchett 1997; Okunmadewa,Yusuf, \& Omonona, 2007; Yusuf, 2008; Adepoju \& Oni, 2012; Adepoju, Timothy,\& Oyekale, 2013; Olowe et al., 2014). Risk aversion of poultry farmers has also been documented in the literature (Ajetomobi \& Binuomote, 2006; Ayinde et al., 2012; Salman, Ashagidigbi \& Jabar, 2014). However, little is known about the relationship between social capital and risk attitude of poultry farmers in Nigeria. This study investigated the causality between social capital and risk attitude of small-scale commercial poultry farmers in Oyo state.

\section{Materials and Methods}

Primary data were collected using a two-stage sampling procedure. The first stage was a purposive selection of Ido and Oluyole Local Government Areas (LGAs) out of the six LGAs in the suburbs of Ibadan city owing to a high concentration of poultry farms in the LGAs. Sequel to this, a random selection of two hundred small-scale poultry farmers was done. Small scale poultry production was categorised between 500-2500 birds FAO (2008). The semi-structured questionnaire sought information on the socioeconomic characteristics of the farmers, the sources of risks to farmers, the dimensions of social capital and the effect of social capital on risk attitude of small scale poultry farmers.

Six social capital indices were estimated. Cash contribution is the annual membership due paid to the various associations, which the household members belong to. Cash contribution reveals members commitment to the group and the coefficient is expected to be positive (Grootaert, 1998). Labour contribution is the total number of days worked by household members or the number of days worked in a year as membership contribution. Decision Making is average participation in the decision making of the three most important groups to them multiplied by 100 for each household. Heterogeneity index is an aggregation of variation of members of the three most important institutions to the households with respect to differences within kin groups, occupation, economic status, religion, gender, age group and same occupation. The highest attainable heterogeneity score of 10 was assigned to each association. The sum of scores for each household was then divided by 30 to obtain an index and then multiplied by hundred. Membership Density is the summation of the total number of associations to which each household belongs. Meeting Attendance Index was estimated by the ratio of total attendance of household members at meetings to the number of scheduled meetings of the three most important associations in a year. The value was then multiplied by 100 (Maluccio, Haddad \& May, 2000; Aker, 2005). Aggregate social capital index is also known as the multiplicative social capital index. The index was calculated using the products of density of membership, heterogeneity index and decision making index of households in their various social groups.

Data were analysed using descriptive statistics, factorial analysis, multinomial logit and a two-stage least square. Factor analysis was used to reduce variables and to identify a small number of factors that explained most of the variance observed in most of the manifest variables. It was used to bring intercorrelated variables together under more general underlying variables, which were used to categorize the farmers into risk attitude groups (risk preferring, risk neutral and risk averse). Descriptive statistics were used to profile the risk attitude categories of the farmers.

The multinomial logit regression model was used to determine the risk attitude of small scale farmers. The multinomial model is explicitly expressed as: 


$$
\begin{aligned}
& Y_{1}=\propto_{1}+\beta_{1} X_{1}+\cdots \beta_{n} X_{n}+\varepsilon_{i} \\
& Y_{2}=\propto_{2}+\beta_{2} X_{2}+\cdots \beta_{n} X_{n}+\varepsilon_{i} \\
& Y_{3}=\propto_{3}+\beta_{3} X_{3}+\cdots \beta_{n} X_{n}+\varepsilon_{i}
\end{aligned}
$$

Where $\mathrm{Y}_{\mathrm{i}}$ represents three unordered categories of risk attitude:

$\mathrm{Y}_{1}=$ those who were risk averse

$\mathrm{Y}_{2}=$ those who were risk neutral

$\mathrm{Y}_{3}=$ those who were risk takers

$X_{1}-X n$ represent vector of the explanatory variables

$\beta_{1}-\beta n$ represent the parameter coefficients

$\varepsilon i=$ represents the independently distributed error terms

$\propto_{1}-\propto_{3}$ are the intercepts or constant terms

Two-Stage Least Square (2SLS) regression was estimated to assess the endogeneity effect of social capital on risk attitude of farmers. This technique is used when the endogenous variable's error terms are correlated with the exogenous variables. Instrumental Variables (IV) were used to cut correlations between the error term and social capital index. The 2SLS reduces the correlation of the explanatory endogenous variable with the error term Olayemi (1998) and was therefore used to estimate bicausality between social capital and risk attitude of farmers. An instrumental variable $\mathrm{Z}$ is defined as:

$$
\begin{gathered}
X=g(Z, U) \\
Y=f(X, U)
\end{gathered}
$$

where $f$ and $g$ are two random functions and $Z$ is autonomous of $U$. However, the measurements of $Z, X$ and $Y$ do not allow for the identification of the average causal effect of $X$ on $Y$.

Earlier studies used trust as an instrumental variable to verify the endogeneity effect of social capital (Narayan \& Prichett, 1997; Grootaert, 2001; Grootaert \& Bastelaer, 2002; Okunmadewa, Yusuf, \& Omonona, 2007). However, the limitations of trust as an instrument for social capital were acknowledged by Putnam (2000) and Yusuf (2008). We therefore used other instruments proposed by Aker (2005), which are household's length of residency in its present locations, charity contribution in the past year and membership of a faith-based organization.

\section{Results and Discussion \\ Classification of poultry farmers according to their risk attitude}

The explanatory factor analysis on the scale items yielded Eigen values which exceeded one (Table 1). The total variance explained by factors 1,2 and 3 were $39.8,19.3$ and $17.4 \%$ that amount to $76.6 \%$. Validity of the data was examined using Kaiser-Meyer-Ohlin (KMO) measure of sample adequacy and Barlett's test of sphericity. These tests satisfied the validity of data for factor analysis (Table 2).

On the basis of the following questions, the first three items made up scale 1 while the last three items made up scale 2 . The reliability scale ranges from zero to one, with higher values indicating greater reliability (Malhotra, 2010; Cronbach, 1951) (Table 3). Scaling was from -2 for strongly risk seeking to 2 for strongly risk averse as used by Franken, Pennings, \& Garcia, 2014.

Based on this scale, all the sampled farmers were grouped into risk averse, risk neutral and risk taker using the average sum of the score of the items of the more reliable scale which are items 2 and 3, farmers with a negative score were risk takers; those with a score of zero were neutral; and those with a positive score were risk averse.

\section{Result of Factor Analysis}

Table 1

\begin{tabular}{|c|c|c|c|c|c|c|}
\hline \multicolumn{7}{|c|}{ Total Variance Explained } \\
\hline \multirow{2}{*}{ Component } & \multicolumn{5}{|c|}{ Initial Eigen Value } & \multicolumn{2}{c|}{ Extraction Sums of Squared Loadings } \\
\cline { 2 - 7 } & Total & \% of variance & Cumulative \% & Total & $\%$ of variance & Cumulative \% \\
\hline 1 & 2.36 & 39.772 & 39.772 & 2.36 & 39.772 & 39.772 \\
\hline 2 & 1.163 & 19.383 & 59.1552 & 1.163 & 19.333 & 59.158 \\
\hline 3 & 1.046 & 17.430 & 76.585 & 1.046 & 17.430 & 76.585 \\
\hline 4 & 0.620 & 10.333 & 86.918 & & & \\
\hline 5 & 0.444 & 7.395 & 94.314 & & & \\
\hline 6 & 0.341 & 5.685 & 100.0 & & & \\
\hline
\end{tabular}




\section{KMO and Bartlett's Test}

\begin{tabular}{|l|l|l|}
\hline Kaiser-Meyer-Olkin Measure of Sampling Adequacy & & 0.615 \\
\hline Bartlett's Test of Sphericity & Approx. Chi Square & 255.098 \\
\hline & Df. & 15 \\
\cline { 2 - 3 } & Sig. & .0000 \\
\hline Cronbach's Alpha & & No of Items \\
\hline 0.655 & & 6 \\
\hline
\end{tabular}

Table 3

Factor Analysis and Reliability

\begin{tabular}{|l|l|l|}
\hline $\mathbf{S} / \mathbf{N}$ & \multicolumn{1}{|c|}{ Items } & \multicolumn{1}{|c|}{ Factor loading } \\
\hline 1 & I prefer production certainty to uncertainty & 0.618 \\
\hline 2 & I am willing to take higher production risk in order to realize higher output & 0.722 \\
\hline 3 & I always love taking production risk & 0.744 \\
\hline 4 & $\begin{array}{l}\text { I am willing to take higher production risks in order to realize higher average } \\
\text { returns }\end{array}$ & 0.663 \\
\hline 5 & I easily adopt new technology & 0.645 \\
\hline 6 & I give birds vaccination as at when due & 0.270 \\
\hline
\end{tabular}

\section{Risk Attitude Profile}

Results showed that $52.5 \%, 37.5 \%$ and $10 \%$ of the poultry farmers were risk averse, risk neutral and risk preferring, respectively. This is consistent with apriori expectation that most farmers are risk averse and also in agreement with various studies (Salimonu \& Falusi, 2009; Sekar \& Ramasamy, 2001). A higher proportion of the poultry farmers (51.50\%) were in the age bracket of 41-50 years (Table 4). This is similar to Ajetomobi and Binuomote (2006) where a third of the respondents were within the age range of 41 to 50 . These farmers belonged to the active labour force and were expected to manage their farms effectively. However, about a tenth of the risk averse and risk neutral farmers were less than thirty years old respectively while a tenth of the risk takers were within 51 to 60 years of age. A higher percentage of the female farmers $(68.57 \%)$ were risk averse than their male counterparts (31.43) owing to the fact that female farmers are often faced with lack of access to productive assets owing to gender inequality. About half of both the male and female farmers, respectively were risk averse while about $12 \%$ and $0.67 \%$ of the male and female farmers respectively were risk preferring. About two-thirds of the farmers were married while the rest were unmarried (single, divorced and widowed).
A majority of the risk averse $(65.71 \%)$, risk neutral $(69.33 \%)$ and risk preferring $(50 \%)$ farmers were married. About two-fifth of the farmers had university education while a tenth of them had no formal education. About $95 \%$ of the risk prefers had tertiary education while about $54 \%$ of farmers with secondary education were risk neutral. The result is similar to the findings of Ajetomobi and Binuomote (2006) that most poultry farmers have formal education. In a typical African setting, most households are extended (Mberu, 2007). A typical poultry farming household had five members which is small when compared to Kouame (2010) where the average household size was 13 members. About a third of the rural households had more than four to five family members while those with four to five members had the highest frequency and were risk averse.

\section{Distribution of respondents based on assets characteristics and risk attitude}

A majority of the farmers have 6-10 years of experience in poultry farming. About $48.57 \%$ of the farmers with one to five years of farming experience were risk averse, $57.33 \%$ were risk neutral and 50\% were risk preferring representing $52 \%$ of the sampled farmers (Table 5). With respect to access to credit, about $67 \%$ of all the farmers and a higher proportion of the farmers in all the risk groups had access to 
Risk Attitude and Socioeconomic Characteristics

\begin{tabular}{|c|c|c|c|c|}
\hline $\begin{array}{c}\text { Socioeconomic } \\
\text { variables }\end{array}$ & $\begin{array}{c}\text { Risk Averse } \\
\mathrm{N}=(\mathbf{1 0 5})\end{array}$ & $\begin{array}{c}\begin{array}{l}\text { Risk Neutral } \\
\mathbf{N}=(\mathbf{7 5})\end{array} \\
\end{array}$ & $\begin{array}{c}\text { Risk Preferring } \\
\mathbf{N}=\mathbf{( 2 0 )}\end{array}$ & $\begin{array}{c}\text { Total } \\
\mathbf{N}=(\mathbf{2 0 0})\end{array}$ \\
\hline \multicolumn{5}{|l|}{ Age } \\
\hline $21-30$ & $10(9.52)$ & $8(10.67)$ & $6(30.00)$ & $24(12.00)$ \\
\hline $31-40$ & $25(23.81)$ & $15(20.00)$ & $3(15.00)$ & $43(21.50)$ \\
\hline $41-50$ & $47(44.76)$ & $40(53.33)$ & $9(45.00)$ & $96(48.00)$ \\
\hline $51-60$ & $23(21.90)$ & $12(16.00)$ & $2(10.00)$ & $37(18.50)$ \\
\hline \multicolumn{5}{|l|}{ Gender } \\
\hline Female & $33(31.43)$ & $23(32.00)$ & $4(20.00)$ & $60(30.50)$ \\
\hline Male & $72(68.57)$ & $51(68.00)$ & $17(80.00)$ & $140(69.50$ \\
\hline \multicolumn{5}{|l|}{ Marital status } \\
\hline Single & $18(17.14)$ & $14(18.67)$ & $7(35.00)$ & $39(19.50)$ \\
\hline Married & $69(65.71)$ & $52(69.33)$ & $10(50.00)$ & $131(65.50)$ \\
\hline Divorced & $6(5.71)$ & $8(10.67)$ & $3(15.00)$ & $17(8.50)$ \\
\hline Widowed & $12(11.43)$ & $1(1.33)$ & $0(0.00)$ & $13(6.50)$ \\
\hline \multicolumn{5}{|l|}{ Educational status } \\
\hline No formal education & $9(8.57)$ & $11(14.67)$ & $0(0.00)$ & $20(10.00)$ \\
\hline Primary & $13(12.38)$ & $20(26.67)$ & $3(15.00)$ & $36(18.00)$ \\
\hline Secondary & $10(9.52)$ & $12(16.00)$ & $0(0.00)$ & $22(11.00)$ \\
\hline Post-secondary & $53(50.48)$ & $26(34.67)$ & $8(40.00)$ & $87(43.50)$ \\
\hline Postgraduate & $20(19.05)$ & $6(8.00)$ & $9(45.00)$ & $35(17.50)$ \\
\hline \multicolumn{5}{|l|}{ Household size } \\
\hline $2-3$ & $15(14.29)$ & $4(5.33)$ & $6(30)$ & $25(12.50)$ \\
\hline $4-5$ & $56(53.33)$ & $41(54.67)$ & $14(70)$ & $111(55.50)$ \\
\hline 6-8 & $34(32.38)$ & $30(40)$ & $0(0.00)$ & $64(32.00)$ \\
\hline
\end{tabular}

Note: Figures in parenthesis are $\%$.

credit. Membership of a poultry farmers' association is expected to improve farming system, management and income. Two-fifths of the farmers did not belong to poultry farmers association and they formed the highest proportion of farmers in the three risk groups.

\section{Distribution of respondents based on farm characteristics and risk attitude}

Based on the source of water available to the farmers, $51.50 \%$ of them had a borehole as their source of water, $44.50 \%$ had a well as source of water and $4.50 \%$ of the farmers had a river as the source of water which is the least of all (Table 6). More than half of poultry farmers used a borehole as source of water, this may be because poultry farmers are more educated and recognize the importance of a good water source for their business Risk taker farmers had the highest percentage $55 \%$ of those using a borehole, risk averse farmers had the highest percentage $48 \%$ farmers that use a well as their source of water and risk neutral farmers had the highest percentage $5 \%$ of those who depend on a river as their source of water. The result of the percentage of income spent on farming shows that those farmers that spent between $26-55 \%$ had the highest percentage, which is $46 \%$, and those that spent $86-100 \%$ had the lowest percentage, which is 


\section{Risk Attitude and Assets}

Table 5

\begin{tabular}{|l|l|l|l|l|}
\hline \multicolumn{1}{|c|}{ Assets characteristics } & \multicolumn{1}{c|}{$\begin{array}{c}\text { Risk Averse } \\
=(\mathbf{1 0 5})\end{array}$} & $\begin{array}{c}\text { Risk Neutral } \\
=(\mathbf{7 5})\end{array}$ & $\begin{array}{c}\text { Risk Taker } \\
=(\mathbf{2 0})\end{array}$ & \multicolumn{1}{|c|}{ Total } \\
\hline Farming Experience(years) & & & & \\
\hline $1-5$ & $51(48.57)$ & $43(57.33)$ & $10(50.00)$ & $104(52.00)$ \\
\hline $6-10$ & $46(43.81)$ & $20(29.33)$ & $10(50.00)$ & $78(39.00)$ \\
\hline $11-15$ & $8(7.62)$ & $10(13.33)$ & $0(0.00)$ & $18(9.00)$ \\
\hline Access to Credit & & & & \\
\hline Yes & $76(72.38)$ & $47(62.67)$ & $11(55.00)$ & $134(67.00)$ \\
\hline No & $29(27.62)$ & $28(37.33)$ & $9(45.00)$ & $66(33.00)$ \\
\hline Poultry Association Membership & & & & \\
\hline Yes & $43(40.95)$ & $29(38.67)$ & $9(45.00)$ & $81(40.50)$ \\
\hline No & $62(59.05)$ & $46(61.33)$ & $11(55.00)$ & $119(59.50)$ \\
\hline Annual Income (Quartile) & & & & \\
\hline $1^{\text {st }}$ & $16(15.26)$ & $9(12)$ & $1(5)$ & $26(13)$ \\
\hline $2^{\text {nd }}$ & $41(39.05)$ & $27(36)$ & $7(35)$ & $75(37.5)$ \\
\hline $3^{\text {rd }}$ & $20(17.14)$ & $27(36)$ & $6(35)$ & $53(26.5)$ \\
\hline $4^{\text {th }}$ & $28(26.6)$ & $27(16)$ & $6(35)$ & $46(23)$ \\
\hline
\end{tabular}

Note: Figures in parenthesis are $\%$.

$3 \% .60 .95 \%$ of the farmers that are risk averse spent between $26-55 \%, 38.67 \%$ of the risk neutral farmers spent between $56-85 \%$ of their income on poultry farming, $45 \%$ of the risk taker spent between $1-25 \%$ of their income on poultry farming. On the result of number of family labour employed, $54 \%$ of the farmers employed one family labour, $25 \%$ of them do not employ any family labour, $2.67 \%$ of the risk neutral farmers employed four family labour, $62.67 \%$ of the risk neutral famers employed one family labour, $20.95 \%$ of the risk averse farmers employed three family labour. The results of number of hired labour employed show that $59 \%$ of all the famers did not employ any hired labour. This is because they are small scale poultry farmers: $3.50 \%$ of all the levels of risk attitude had four hired labour.

\section{Risk Attitude and Farm Characteristics}

\begin{tabular}{|l|l|l|l|l|}
\hline \multicolumn{1}{|c|}{ Farm Characteristics } & $\begin{array}{c}\text { Risk Averse } \\
\mathbf{N = ( 1 0 5 )}\end{array}$ & \multicolumn{1}{|c|}{$\begin{array}{c}\text { Risk Neutral } \\
\mathbf{N = ( 7 5 )}\end{array}$} & \multicolumn{1}{|c|}{$\begin{array}{c}\text { Risk Taker } \\
\mathbf{N = ( 2 0 )}\end{array}$} & \multicolumn{1}{|c|}{$\begin{array}{c}\text { Total } \\
\mathbf{N}=(\mathbf{2 0 0})\end{array}$} \\
\hline Source of Water & & & & \\
\hline Well & $43(40.95)$ & $36(48.00)$ & $9(45.00)$ & $88(44.00)$ \\
\hline Borehole & $57(54.29)$ & $35(46.67)$ & $10(50.00)$ & $103(51.50)$ \\
\hline River & $5(4.76)$ & $4(5.33)$ & $1(5.00)$ & $9(4.50)$ \\
\hline \% of Income Spent on Farming & & & & \\
\hline $1-25$ & $12(11.43)$ & $25(33.33)$ & $9(45.00)$ & $46(23.00)$ \\
\hline $26-55$ & $64(60.95)$ & $21(28.00)$ & $7(35.00)$ & $92(46.00)$ \\
\hline $56-85$ & $25(23.81)$ & $29(38.67)$ & $1(5.00)$ & $55(27.50)$ \\
\hline $86-100$ & $4(3.81)$ & $0(0.00)$ & $3(15.00)$ & $7(3.50)$ \\
\hline No Family Labour Employed & & & & \\
\hline 0 & $27(25.71)$ & $16(21.33)$ & $7(35.00)$ & $50(25.00)$ \\
\hline
\end{tabular}




\begin{tabular}{|l|l|l|l|l|}
\hline 1 & $53(50.48)$ & $47(62.67)$ & $8(40.00)$ & $108(54.00)$ \\
\hline 2 & $22(20.95)$ & $9(12.00)$ & $4(20.00)$ & $35(17.50)$ \\
\hline 3 & $3(2.86)$ & $1(1.33)$ & $0(0.00)$ & $4(2.00)$ \\
\hline 4 & $0(0.00)$ & $2(2.67)$ & $1(5.00)$ & $3(1.50)$ \\
\hline No of Hired Labour Employed & & & & \\
\hline 0 & $59(56.19)$ & $47(62.67)$ & $12(60.00)$ & $118(59.00)$ \\
\hline 1 & $19(18.10)$ & $11(14.67)$ & $7(35.00)$ & $37(18.50)$ \\
\hline 2 & $19(18.10)$ & $12(16.00)$ & $0(0.00)$ & $31(15.50)$ \\
\hline 3 & $3(2.86)$ & $3(4.00)$ & $1(5.00)$ & $7(3.50)$ \\
\hline 4 & $5(4.76)$ & $2(2.67)$ & $0(0.00)$ & $7(3.50)$ \\
\hline No of Birds & & & & \\
\hline $1-500$ & $82(78.10)$ & $53(70.67)$ & $19(95.00)$ & $154(77.00)$ \\
\hline $501-1000$ & $17(16.19)$ & $18(24.00)$ & $0(0.00)$ & $35(17.50)$ \\
\hline $1001-1500$ & $4(3.81)$ & $0(0.00)$ & $1(5.00)$ & $5(2.50)$ \\
\hline $1501-2000$ & $2(1.90)$ & $2(2.67)$ & $0(0.00)$ & $4(2.00)$ \\
\hline $2001-2500$ & $0(0.00)$ & $2(2.67)$ & $0(0.00)$ & $2(1.00)$ \\
\hline
\end{tabular}

Note: Figures in parenthesis are $\%$.

Distribution of respondents based on social capital dimensions and risk attitude

With respect to decision making index, about a fifth, a quarter and two-thirds of the risk averse, risk neutral and risk takers respectively contributed 21$30 \%$ of the decisions in the associations (Table 7). Heterogeneity of social groups was generally low among the poultry farmers. The $14 \%$ of the farmers belonged to homogeneous groups while $45 \%$ of them belonged to groups with six to ten heterogeneity score, and they had the highest percentage in the three risk groups. Risk averse individuals must have been exposed to different kind of risk at one time or the other and unwilling to experience it again. In the area of cash contribution, the highest percentage of farmers fell within the cash contribution of NGN 20001 to NGN 30000. Further, 40.95\% were risk averse, $37.33 \%$ were risk neutral while $20 \%$ were risk takers.

Risk Attitude and Social Capital Dimensions

\begin{tabular}{|l|l|l|l|l|}
\hline \multicolumn{1}{|c|}{ Social capital dimensions } & \multicolumn{1}{|c|}{$\begin{array}{c}\text { Risk Averse } \\
\mathbf{N = ( 1 0 5 )}\end{array}$} & $\begin{array}{c}\text { Risk Neutral } \\
\mathbf{N}=(\mathbf{7 5})\end{array}$ & $\begin{array}{c}\text { Risk Taker } \\
\mathbf{N = ( 2 0 )}\end{array}$ & \multicolumn{1}{c|}{$\begin{array}{c}\text { Total } \\
\mathbf{N}=(\mathbf{2 0 0})\end{array}$} \\
\hline Decision Making Index & & & & \\
\hline 0 & $10(9.52)$ & $16(21.33)$ & $0(0.00)$ & $26(13.00)$ \\
\hline $1-10$ & $25(23.81)$ & $16(21.33)$ & $4(20.00)$ & $45(22.50)$ \\
\hline $21-30$ & $21(20.00)$ & $20(26.67)$ & $13(65.00)$ & $54(27.00)$ \\
\hline $31-40$ & $49(46.67)$ & $23(30.67)$ & $3(15.00)$ & $75(37.50)$ \\
\hline Heterogeneity Index(\%) & & & & \\
\hline 0 & $7(6.67)$ & $18(24.00)$ & $3(15.00)$ & $28(14.00)$ \\
\hline $6-10$ & $50(47.62)$ & $31(41.33)$ & $9(45.00)$ & $90(45.00)$ \\
\hline $11-16$ & $48(45.71)$ & $26(34.67)$ & $8(40.00)$ & $82(41.00)$ \\
\hline Membership Density Index & & & & \\
\hline 0 & $10(9.52)$ & $16(21.33)$ & $0(0.00)$ & $26(13.00)$ \\
\hline 20 & $8(7.62)$ & $7(9.33)$ & $4(20.00)$ & $19(9.50)$ \\
\hline
\end{tabular}




\begin{tabular}{|l|l|l|l|l|}
\hline 40 & $19(18.10)$ & $10(13.33)$ & $0(0.00)$ & $29(14.50)$ \\
\hline 60 & $34(32.38)$ & $23(30.67)$ & $9(45.00)$ & $66(33.00)$ \\
\hline 80 & $26(24.76)$ & $11(14.67)$ & $7(35.00)$ & $44(22.00)$ \\
\hline 100 & $8(7.62)$ & $8(10.67)$ & $0(0.00)$ & $16(8.00)$ \\
\hline Labour Contribution Index(manday) & & & & \\
\hline 0 & $32(30.48)$ & $31(41.33)$ & $3(15.00)$ & $66(33.00)$ \\
\hline $1-20$ & $37(35.24)$ & $17(22.67)$ & $9(45.00)$ & $63(31.50)$ \\
\hline $21-40$ & $14(13.33)$ & $17(22.67)$ & $5(25.00)$ & $36(18.00)$ \\
\hline $41-60$ & $14(13.33)$ & $10(13.33)$ & $3(15.00)$ & $27(13.50)$ \\
\hline $61-80$ & $8(7.62)$ & $0(0.00)$ & $0(0.00)$ & $8(4.00)$ \\
\hline Cash contribution (N) & & & & \\
\hline 0 & $12(11.43)$ & $14(18.67)$ & $0.00 \%$ & $26(13.00)$ \\
\hline $1-10000$ & $7(6.67)$ & $5(6.670$ & $2(10.00)$ & $14(7.00)$ \\
\hline $10001-20000$ & $26(24.76)$ & $14(18.67)$ & $13(65.00)$ & $53(26.50)$ \\
\hline $20001-30000$ & $43(40.95)$ & $28(37.33)$ & $4(20.00)$ & $75(37.50)$ \\
\hline $30001-40000$ & $8(7.62)$ & $10(13.33)$ & $1(5.00)$ & $19(9.50)$ \\
\hline $40001-50000$ & $5(4.76)$ & $0(0.00)$ & $0(0.00)$ & $5(2.50)$ \\
\hline $50001-60000$ & $5(1.90)$ & $2(2.67)$ & $0(0.00)$ & $4(2.00)$ \\
\hline $60001-70000$ & $2(1.90)$ & $2(2.67)$ & $0(0.00)$ & $4(2.00)$ \\
\hline Meeting Attendance Index & & & & \\
\hline 0 & $112(1.43)$ & $16(21.33)$ & $0(0.00)$ & $28(14.00)$ \\
\hline $21-40$ & $1(0.95)$ & $2(2.67)$ & $0(0.00)$ & $3(1.50)$ \\
\hline $41-60$ & $6(5.71)$ & $2(2.67)$ & $1(5.00)$ & $9(4.50)$ \\
\hline $61-80$ & $33(31.43)$ & $22(29.33)$ & $11(55.00)$ & $66(33.00)$ \\
\hline $81-100$ & $53(50.48)$ & $33(44.00)$ & $8(40.00)$ & $94(47.00)$ \\
\hline Aggregate social capital Index & & & & \\
\hline $0-19.99$ & $54(51.43)$ & $38(50.67)$ & $13(65)$ & $105(52.50)$ \\
\hline $20.00-39.99$ & $45(42.86)$ & $33(44)$ & $7(35)$ & $85(42.50)$ \\
\hline $40.00-59.99$ & $6(5.71)$ & $3(4)$ & $0(0)$ & $9(4.50)$ \\
\hline $60.00-79.99$ & $0(0)$ & $1(1.30)$ & $0(0)$ & $1(0.50)$ \\
\hline & & & & \\
\hline & & & & \\
\hline
\end{tabular}

Figures in parenthesis are \%.

\section{Determinants of Risk Attitude of Small} Scale Farmers

Attitude towards risk is a variable that measures farmers' willingness to take risks which is an important determinant in their decision to produce. The result of the multinomial logistics regression indicated that the chi square was 70.55 and significant at $1 \%$ suggesting that the independent variables jointly accounts for the variations in the dependent variables (Table 8). The choice of being risk averse was affected by marital status, educational level, family size, percentage spent on poultry income and aggregate social capital. The coefficient of marital status had a positive relationship with the log-likelihood of being risk averse. Similarly, the coefficients of years of formal education had a positive relationship with being risk preferring but reduced the log-likelihood of being risk averse suggesting that an additional year of formal education would increase the likelihood of a farmer adopting innovation. This follows apriori expectation that formal educational is positively related to being a risk preferer (Babalola, 2014; Dohmen et al., 2012). Further, a unit increase in social capital index and percentage of income spent on farming would increase the log-likelihood of being risk averse by 0.235 unit and 0.838 unit respectively.

However, an additional household member would reduce the likelihood of being risk averse and risk taking by 0.023 unit and 0.837 unit respectively. This supports the findings of Babatunde, Adekunle, \& 
Determinant of risk attitude of poultry farmers

\begin{tabular}{|c|c|c|c|c|c|c|c|c|}
\hline \multirow[b]{2}{*}{ Variable } & \multicolumn{3}{|c|}{ Risk Averse } & \multicolumn{3}{|c|}{ Risk Preferer } & \multirow{2}{*}{\begin{tabular}{|c|}
$\begin{array}{c}\text { Risk } \\
\text { Neutral }\end{array}$ \\
dy/dx
\end{tabular}} & \multirow[b]{2}{*}{ S.E } \\
\hline & $d y / d x$ & SE & $\begin{array}{c}\text { Relative } \\
\text { Risk } \\
\text { Ratio }\end{array}$ & $d y / d x$ & SE & $\begin{array}{c}\text { Relative } \\
\text { Risk } \\
\text { Ratio }\end{array}$ & & \\
\hline Age & 0.0187 & 0.0325 & 1.0188 & -0.0474 & 0.0533 & 0.9536 & $-.112 * * *$ & .0390 \\
\hline Gender & 0.1411 & 0.3953 & 1.1516 & $1.6739 * *$ & 0.8495 & 5.3332 & .9992 & .7893 \\
\hline Marital status & $0.5287^{*}$ & 0.3156 & 1.6968 & 0.6535 & 0.4850 & 1.9221 & .2496 & .5037 \\
\hline $\begin{array}{l}\text { Educational } \\
\text { level }\end{array}$ & $-0.4811 * *$ & 0.1569 & 1.6178 & $0.6801 * *$ & 0.2809 & 1.9742 & $.4851 *$ & .2711 \\
\hline Household size & $-0.3926^{* * *}$ & 0.1716 & 0.6753 & $-0.8369 * *$ & 0.3003 & 0.4330 & -.3211 & .7187 \\
\hline $\begin{array}{l}\text { Access to } \\
\text { credit }\end{array}$ & 0.3879 & 0.4269 & 1.4740 & -0.7263 & 0.6733 & 0.4836 & .1568 & .5073 \\
\hline Experience & -0.0231 & 0.0762 & 0.9771 & 0.0703 & 0.1294 & 1.0728 & .4801 & .4266 \\
\hline $\begin{array}{l}\text { Source of } \\
\text { water }\end{array}$ & -0.2570 & 0.3074 & 0.7733 & 0.4892 & 0.4848 & 1.6310 & .0000 & .0001 \\
\hline $\begin{array}{l}\% \text { spent on } \\
\text { farming }\end{array}$ & $0.8378 * *$ & 0.2426 & 2.3113 & 0.4392 & 0.3881 & 1.5515 & $6.34 \mathrm{e}-07$ & $2.01 \mathrm{e}-6$ \\
\hline $\begin{array}{l}\text { No of labour } \\
\text { employed }\end{array}$ & $3.11 \mathrm{e}-06$ & $1.19 \mathrm{e}-05$ & 1.000003 & $3.04 \mathrm{e}-05$ & $1.85 \mathrm{e}-05$ & 1.00003 & .0302 & .0311 \\
\hline $\begin{array}{l}\text { Per capital } \\
\text { expenditure }\end{array}$ & $-2.37 \mathrm{e}-06$ & $1.45 \mathrm{e}-06$ & 0.9999 & $-2.55 e-06$ & $2.27 \mathrm{e}-06$ & 0.9999 & $-.0009 * *$ & .0048 \\
\hline $\begin{array}{l}\text { Aggregate } \\
\text { social capital }\end{array}$ & $0.2345^{*}$ & 0.1178 & 1.000005 & 0.5371 & 0.0567 & 0.9999 & $-.2108 * *$ & .0978 \\
\hline
\end{tabular}

Risk Neutral $=$ Base $\quad$ Log Likelihood $=-154.2138 \quad$ LR Chi $(36)=70.55 \quad$ Prob $>\mathrm{Chi}^{2}=0.0000$

Pseudo $\mathrm{R}^{2}=0.1861$ No of Observation $=200 \quad * * *$ significant at $1 \%$, ** significant at $5 \%$, * significant at $10 \%$.

Olagunju, (2012); Balogun et al., (2011) that a unit increase in family size will reduce the likelihood of being a risk taker. Likewise, an additional year of age, unit of per capita monthly expenditure and unit of social capital would reduce the log-likelihood of being risk neutral by 0.112 unit, 0.009 unit and 0.211 unit respectively.

\section{Endogeneity Effects of Social Capital on risk attitude of farmers}

In order to assess and correct for endogeneity of social capital, a two-stage least square regression model was constructed (Table 9). A Pearson product moment correlation analysis between aggregate social capital and the instrumental variables showed that length of residency was the only significant $(\mathrm{P}<0.001)$ instrument. Length of residency is highly correlated with social capital and uncorrelated with risk attitude because social networks are built over time (Glasear et al., 2000).

The adjusted $\mathrm{R}^{2}$ increased from 0.5802 (with actual social capital index) to 0.5836 in the second stage with instrumental variables (Table 10). Similarly, the coefficient of social capital index in the 2SLS increased from 0.0413 to 0.0481 relative to the OLS

\section{Correlation Result}

Table 9

\begin{tabular}{|l|l|l|l|}
\hline & Length of residency & Membership in religious group & Charity donation \\
\hline Aggregate social capital & $\begin{array}{l}0.095 \\
(0.000)\end{array}$ & $\begin{array}{l}0.121 \\
(0.089)\end{array}$ & $\begin{array}{l}0.324 \\
(0.179)\end{array}$ \\
\hline Remark & Significant at $1 \%$ & Significant at $10 \%$ & Not significant \\
\hline
\end{tabular}


Estimation of endogeneity effects of social capital

\begin{tabular}{|l|l|l|l|l|}
\hline \multicolumn{1}{|c|}{ Variable } & \multicolumn{2}{c|}{ OLS } & \multicolumn{2}{c|}{ 2SLS } \\
\hline & \multicolumn{1}{c|}{ Coefficient } & \multicolumn{1}{c|}{ T } & \multicolumn{1}{c|}{ Coefficient } & \multicolumn{1}{c|}{ T } \\
\hline Age & .0015 & 1.40 & $-3.07 \mathrm{e}-07$ & -0.74 \\
\hline Gender & $.0296^{* *}$ & 2.22 & $.0007^{* *}$ & 0.41 \\
\hline Marital status & .0057 & 0.59 & .0296 & 2.21 \\
\hline Education & .0031 & 0.62 & .01001 & 0.83 \\
\hline Family size & $-.0185^{* *}$ & -3.29 & .0033 & 0.67 \\
\hline Access to credit & $-.0238^{*}$ & -1.77 & $-.0139 *$ & -1.48 \\
\hline Experience & -.0017 & -0.64 & -.0276 & -1.86 \\
\hline Source of water & -.0078 & -0.77 & .0009 & 0.17 \\
\hline$\%$ spent on poultry & $.1141^{* * *}$ & 15.12 & $-.0072^{* * *}$ & -0.71 \\
\hline Number of labour & $-1.04 \mathrm{e}-07$ & -0.27 & .1139 & 15.20 \\
\hline Per capital expenditure & $-1.36 \mathrm{e}-07^{*}$ & -2.75 & $-1.75 \mathrm{e}-07$ & -0.44 \\
\hline Aggregate social capital & 0.0413 & -0.56 & $0.0481^{* *}$ & -0.64 \\
\hline Cons & -.4343 & 0.87 & .0477 & 0.96 \\
\hline Adjusted $\mathrm{R}^{2}$ & 0.5802 & & 0.5836 & \\
\hline Sample size & 200 & & 200 & \\
\hline
\end{tabular}

$* * *$ Significant at $1 \%, * *$ significant at $5 \%$, * significant at $10 \%$.

estimates. These suggested that social capital is truly exogeneous and corroborated the findings of Narayan and Prichett (1997), Grootaert (1997), Okunmadewa et al. (2007), Aker (2005) and Yusuf (2008).

\section{Conclusion}

This study assessed the effect of social capital associated with risk attitude of small scale poultry farmers in Oyo state Nigeria. Approximately half and a tenth of the farmers were risk averse and risk preferers, respectively. The rest were risk neutral. An additional year of education of the farmers increased the likelihood of being a risk preferer while it reduced the likelihood of being risk averse. Thus, formal education has the potential to enhance the likelihood of adoption of agricultural innovation among the poultry farmers. Knowledge of the determinants of attitudes toward risk is essential for diffusion of new technologies among small-scale farmers and enhancing rural development programmes. Poultry farmers should increase the percentage of their income spent on poultry production since increased farm size leads to increased reduction of risk. Social capital significantly influenced risk attitude among the poultry farmers. Promoting social capital formation among poultry farmers is therefore a risk mitigation scheme to enhance their production.

\section{References}

1. Aboul-Naga, A.M. \& Elbeltagy, A.R. (2007). Animal biotechnology: Applications and implications in the near East and North Africa (NENA) countries. 2086-93. Retrieved 3 May, 2017, from http://aaaid.ae/pdf/magazine5/ Ani\%20Biotechnology\%2086-93.pdf.

2. Adepoju, A.A. \& Oni, O.A. (2012). Investigating endogeneity effects of social capital on household Welfare in Nigeria: A Control Function Approach. Quarterly Journal of International Agriculture 51 (2012), No. 1: 73-96.

3. Adepoju, O.A., Timothy, O.A. \& Oyekale, A.S. (2013). Risk coping behaviour of small scale poultry farmers in Ogun State, Nigeria. Asian Journal of Animal and Veterinary Advances, 8: 786-795.

4. Aker, J.C. (2005). Social Networks and Household Welfare in Tanzania: Working Together to Get Out of Poverty. p 33. Retrieved 21 September, 2017 from: http://www.csae. ox.ac.uk/conferences/2007-EDiA-LaWBiDC/ papers/058-Aker.pdf.

5. Alabi, R.A. \& Isah, A.O. (2002). Poultry production constraints. The case of Esan West Local Government Area of Edo State, Nigeria. African Journal of Livestock Extension 1(1): 58-61. 
6. Ajetomobi, J. \& Binuomote, S.O. (2006). Risk aversion among poultry egg producers in Southwestern Nigeria. International Journal of Poultry Science 5(6): 562-565.

7. Ayinde, O.E., Muchie, M., Adewumi, M.O. \& Abaniyan, E.O. (2012). Risk analysis of gender in innovation system: A case study of production of downy mildew maize resistant variety in Kwara State, Nigeria. Obeche Journal 30(1): 459-465.

8. Babalola, D.A. (2014). Risk preferences and coping strategies among poultry farmers in Abeokuta Metropolis, Nigeria. Global Journal of Science Frontier Research 14(5): 22-29.

9. Babatunde, R.O., Adekunle, A.O. \& Olagunju, F.I. (2012). Effect of poultry production on the poverty status of small scale farmers in Oyo State, Nigeria, Asian Journal of Agriculture and Rural Development 2(4):565 - 578.

10. Balogun, O.L., Yusuf, S.A., Omonona, B.T. \& Okoruwa, V.O. (2011). Social capital and microcredit effects on poverty among the rural households in southwest states, Nigeria APRN. Journal of Agricultural and Biological Science 6(3):48- 59.

11. Boehlje, M. (2002). Risk in U.S. agriculture: New challenges and new approaches. Department of Agricultural Economics, Purdue University, Staff Paper, 02 to 07. November, 2002. p. 30. Retrieved on 21 September, 2017, from http:// ageconsearch.umn.edu/bitstream/28614/1/sp0207.pdf.

12. Coleman, J. (1998). Social capital in the creation of human capital. American Journal of Sociology 94 (supplement): S95-S120.

13. Cronbach, L.J. (1951). Coefficient alpha and the internal structure of tests. Psychometrika, 16:297-334.

14. Dohmen, T., Falk, A., Huffman D. \& Sunde, U. (2012). The intergenerational transmission of risk and trust attitudes. Review of Economic Studies 79: 645-677.

15. Ellis, F. (2000). The Determinants of Rural Livelihood Diversification in Developing Countries. Journal of Agricultural Economics, 51(2): 289-302.

16. Fafchamps, M. (1992). Solidarity networks in preindustrial societies: Rational peasants with a moral economy. Economic Development and Cultural Change 41:147-174.

17. Franken, J.R.V., Pennings, J.M.E. \& Garcia, P. (2014). Measuring the effect of risk attitude on marketing behavior. Agricultural Economics 45 (2014): 1-11.
18. Glaeser, E., Laibson, D., Scheinkman, J. \& Soutter, C. (2000). Measuring trust. Quarterly Journal of Economics 65 (3): 811-846.

19. Grootaert, C. (1998). Social capital: The missing link. Social Capital Initiative Working Paper No. 3 Washington, D.C. p.34. Retrieved on 21 September, 2017 from http://siteresources. worldbank.org/INTSOCIALCAPITAL/ Resources/Social-Capital-Initiative-WorkingPaper-Series/SCI-WPS-03.pdf.

20. Grootaert, C. 2001. Social capital: the missing link in Social Capital and Participation in Everyday Life, edited by Eric M. Uslaner. London. Routledge: 9 - 29 .

21. Grootaert, C., \& Bastelaer, T.V. (2002). Understanding and measuring social capital: a multidisciplinary tool for practitioners. Social Capital Initiative Working Paper No. 24. p. 45. Washington, D.C.: World Bank. 45pp. Retrieved on 21 September, 2017 from http://siteresources. worldbank.org/INTSOCIALCAPITAL/ Resources/Social-Capital-Initiative-WorkingPaper-Series/SCI-WPS-24.pdf

22. Grootaert, C., Narayan, D., Jones, V.N. \& Woolcock, M. (2004). Measuring Social Capital: an integrated questionnaire. World Bank Working Paper No.18: p. 61. Retrieved on 21 September, 2017 from http://documents.worldbank.org/curated/ en/515261468740392133/pdf/281100PAPER0 Measuring0social0capital.pdf.

23. Heise, H., Crisanb, A. \& Theuvsenc, L. (2015). The Poultry market in Nigeria: market structures and potential for investment in the market . International Food and Agribusiness Management Review 18 (Special Issue A):197222.

24. Jussaume, R.A. \& Glenna, L. (2009). Considering structural, individual and social network explanations for ecologically sustainable agriculture: An example drawn from Washington State wheat growers. Sustainability 2009, 1, 120-132; DOI:10.3390/ su1020120.

25. Kouamé, E.B. (2010). Risk, risk aversion and choice of risk management. Strategies by cocoa farmers in western Côte d'Ivoire. Paper presented at the CSAE Conference 2010: Economic Development in Africa, St Catherine's College, Oxford, 21-23 March 2010.

26. Malhotra, N.K. (2010). Marketing research: An applied orientation, (6th Edition), New Delhi: Pearson Education Asia, India: p 929.

27. Maluccio, J., Haddad, L. \& May, J. (2000). Social capital and household welfare in South Africa, 
1993-1998. Journal of Development Studies 36 (5): 56-81.

28. Mberu, B. U. (2007). Household structure and living conditions in Nigeria. Journal of Marriage and Family, 69: 513-527.

29. Narayan, D., \& Pritchett, L. (1997). Cents and sociability: Household income and social capital in rural Tanzania. Econ. Dev. Cult. Change. 47: 871-897.

30. Okunmadewa, F.Y., Yusuf, S.A. and Omonona, B.T. (2007). Social capital and poverty in Nigeria. Pakistan journal of social sciences 4(3): 331-339.

31. Olayemi, J.K. (1998). Elements of Applied Econometrics. Elshaddai Global Ventures Ltd. Nigeria, p. 249.

32. Olowe, O.O, Okunmadewa, F.Y., Yusuf, S.A. \& Oni, O. (2014). Effects of social capital on wellbeing of rural households in Southwest Nigeria. IOSR Journal of Agriculture and Veterinary Science 7(12) 13-21.

33. Picazo-Tadeo, A.J. \& Wall, A. (2011). Production risk, risk aversion and the determination of risk attitudes among Spanish rice producers. Agricultural Economics, Vol. 42, 451-464.

34. Putnam, R. (2000). Bowling Alone - The Collapse and Revival of American Community. Simon \& Schuster, New York NY.

35. Sahel, (2015). An Assessment of the Nigerian Poultry Sector. SAHEL Newsletter, Volume
11, Retrieved on 21 September, 2017, from http://sahelcp.com/wp-content/uploads/2016/12/ Sahel-Newsletter-Volume-11.pdf.

36. Salman, K.K., Ashagidigbi, W.M. \& Jabar, K.T. (2014). Correlates of risk-aversion among poultry egg farmers in Ibadan, Nigeria. Journal of Rural Economics and Development 19(1): 4660.

37. Salimonu, K.K. \& Falusi, A.O. (2009). Sources of risk and management strategies among food crop farmers In Osun State, Nigeria. African Journal of Food Agriculture Nutrition and Development, 9(7): 1591-1605.

38. Sekar, I. and Ramasamy, C. (2001). Risk and resource analysis of rainfed tanks in South India. J. Soc. Econ. Dev., 111: 2. July - December 2001.

39. Yu, X., Hailu, G. \& Cao, J. (2014). Risk Attitudes, Social Interactions and the Adoption of Genotyping in Dairy Production. Selected Paper Prepared for Presentation at Agricultural and Applied Economics Association's 2014 AAEA/EAAE/CAES Joint Symposium "Social Networks, Social Media and the Economics of Food", Montreal, Quebec, Canada, May 28-30, 2014.

40. Yusuf, S.A. (2008). Social capital and household welfare in Kwara State, Nigeria. Journal of Human Ecology 23(3): 219-229. 